GREGORY THE GREAT 


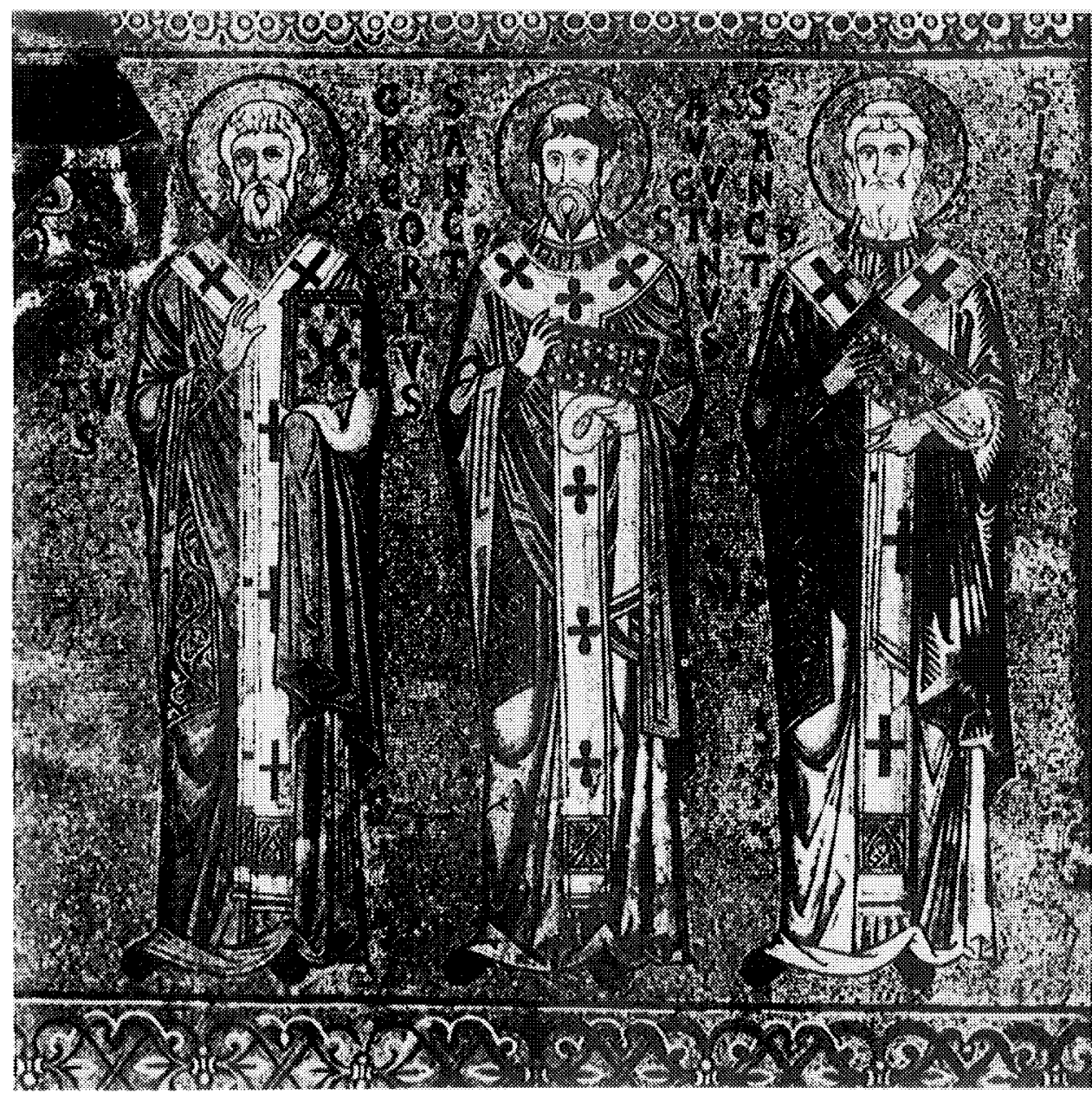

Gregory the Great, from a twelfth-century mosaic in Cefalù cathedral. Courtesy of Alinari. 


\title{
CAROLE STRAW
}

\section{GREGORY THE GREAT}

\author{
PERFECTION \\ IN IMPERFECTION
}

UNIVERSITY OF CALIFORNIA PRESS

Berkeley $\cdot$ Los Angeles $\cdot$ London 
University of California Press

Berkeley and Los Angeles, California

University of California Press, Ltd.

London, England

(C) 1988 by

The Regents of the University of California

Library of Congress Cataloging-in-Publication Data

Straw, Carole Ellen.

Gregory the Great.

(Transformation of the classical heritage; 14)

Bibliography: $p$.

Includes index.

1. Gregory I, Pope, ca. 540-604. I. Title

II. Series

BX1076.S67 $1988 \quad 270.2^{\prime} 092^{\prime} 4[\mathrm{~B}] \quad 87-1667$

ISBN 0-520-05767-8 (alk. paper)

ISBN 0-520-06872-6 (pbk.)

Printed in the United States of America

$\begin{array}{lllllllll}1 & 2 & 3 & 4 & 5 & 6 & 7 & 8 & 9\end{array}$ 


\section{FOR FREDERICK}

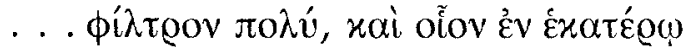

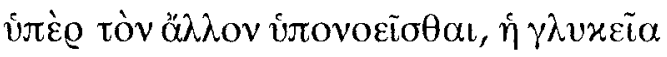

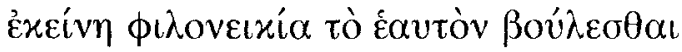

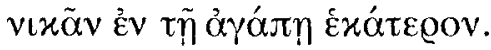

--Gregory of Nyssa, virg. 3.2. 
This page intentionally left blank 